\title{
Juridical Review Consumer Legal Against Labeling Of Food Products Based On Law No. 8 Year 1999
}

\section{Martina Lestari Ritonga}

Sumatera University Faculty Of Law. E-mail: martinaritonga@gmail.com

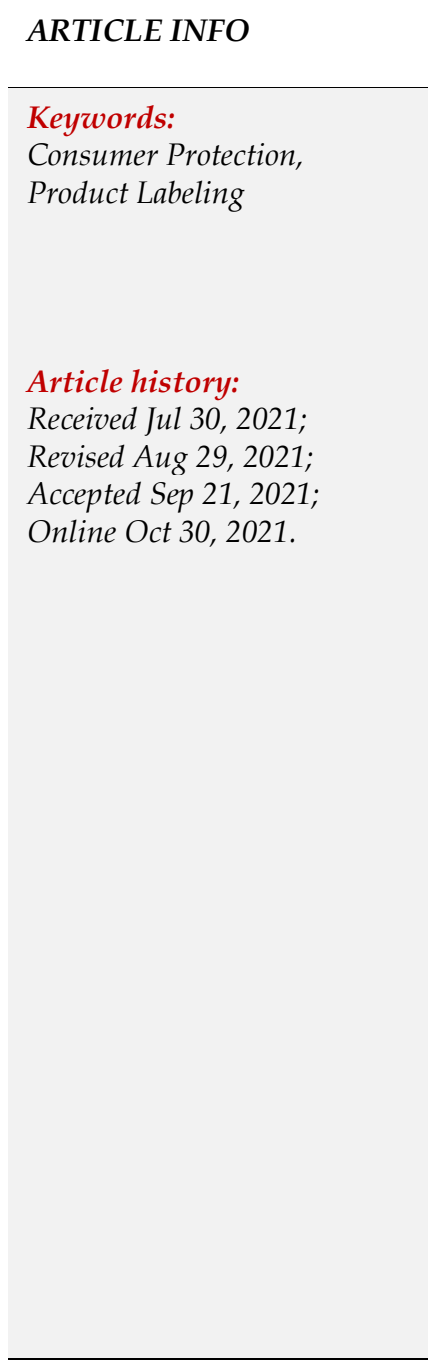
\begin{abstract}
Consumer protection is in line with the development of the world economy. The rapid development of the world economy, especially in the trade sector, produces various types and variations of each type of goods and/or services that can be consumed. For consumers, information about goods and/or services is a basic need, before they use sources of funds to conduct consumer transactions with these goods and/or services. The right to correct information is one of the rights of consumers as regulated in Article 4 of Law no. 8 of 1999 concerning Consumer Protection. One source of the correct information is the label. In article 1 paragraph (3) of PP no. 69 of 1999 concerning Food Labels and Advertisements defines that what is meant by Food Labels is "any information regarding food in the form of pictures, writing, a combination of both or other forms that are attached to food, inserted into, affixed to or part of food packaging". From the definition of the label, it is known that the label contains information about the food produced. However, the problem of labeling, especially regarding food labels, has received less attention from consumers and business actors. Information that is not true and misleads consumers results in losses to consumers which ultimately results in legal consequences for business actors in taking responsibility for them. The type of research used in this research is normative legal research, which is a study that places norms as the object of research in this case is Law no. 8 of 1999. The type of approach used in this research is descriptive analytical approach, namely research based on one or two interrelated variables based on general theories/concepts that are applied to explain a set of data or show comparisons or relationships. Data collection is done by researching library materials (Library Research). Legal data analysis in this paper uses qualitative data. From the results of this research, it can be concluded that the provisions for labeling food products meet the principles of consumer protection and violations of food product labeling by business actors can be subject to civil, criminal and administrative responsibility.
\end{abstract}

This is an open access article under the CC BY-NC license.

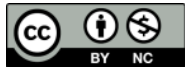

\section{Introduction}

Everyone, at one time, in a single position/alone or in groups with other people, under any circumstances must be a consumer for a certain product or service. This universal situation on several sides shows the existence of various weaknesses in consumers so that consumers do not have a "safe" position. Therefore, basically consumers also need legal protection that is universal. Given the weak position of consumers in general compared to the relatively stronger position of producers in many respects, the discussion of consumer protection will always feel actual and it is always important to study more deeply. 
Protection of consumers is seen materially and formally as increasingly important, given the increasing speed of science and technology which is the driving force for the productivity and efficiency of producers for the goods or services they produce in order to achieve business goals. In order to pursue and achieve these two things, in the end, either directly or indirectly, it is consumers who will generally feel the impact. Thus, efforts to provide adequate protection to the interests of consumers is an important matter and urgent to find a solution, especially in Indonesia.

Consumers whose existence is very unlimited with very varied strata cause producers to carry out marketing and distribution activities of goods and/or services in the most effective way possible in order to reach these very diverse consumers. For this reason, all approaches are pursued so that they have various impacts, including situations that lead to negative and even disgraceful actions that originate from bad intentions. Common adverse effects include, among others, the quality or quality of goods, unclear and even misleading information, forgery and so on.

For consumers, information about goods and or services is a basic need, before he uses his source of funds (salaries, wages, honorariums or whatever other name) to conduct consumer transactions regarding these goods and/or services. With consumer transactions, it is intended to establish legal relations (selling and buying, buying and renting, leasing, borrowing, and so on) regarding consumer products with the business actor. This information includes, among others, the availability of goods or services needed by the consumer community, about product quality, safety, prices, various requirements and/or how to obtain them, product guarantees or guarantees, spare parts inventory, availability of after-sales services, and other matters related to it.

Such information can be obtained from information or materials, oral or written, related business actors (investors, producers, distributors, sellers, sales agents, and other entrepreneurs). Information can also be obtained from the behavior of the government, both in implementing legislation and in carrying out government policies. Furthermore, information about consumer products can also be obtained from the government, consumers or consumer organizations and business actors.

Information on goods and/or services obtained from government circles is absorbed from various explanations, broadcasts, information, drafting of laws and regulations in general or in the context of deregulation, and/or government actions in general or about a consumer product. From the point of view of drafting laws and regulations, it appears that the information is contained as a necessity. Some of them are determined to be made, either by imprinting them on or loading them in containers or their packaging (among other things, labels of packaged food products as regulated in PP No. 69 of 1999 concerning Food Labels and Advertisements). As for other industrial products, information about these products is in the form of standards set by the government, international standards,Information on goods and/or services obtained from consumers or consumer organizations can be seen in word of mouth about a consumer product, letters from readers in the mass media for various broadcasts of certain groups, responses or protests from consumer organizations regarding a consumer product.

In relation to food labels and advertisements which include a statement that the food has complied with these requirements, business actors must be responsible for the truth of the statement. Provisions regarding food safety, quality and nutrition, as well as food labels and advertisements do not only apply to food production that is produced and/or circulated in the territory of the Indonesian state. The same provisions also apply to national food production which is circulated abroad. For food consumers, the majority of whom are Indonesian consumers, they need food products that are safe for the health and safety of their bodies and 
souls. Therefore, what is needed are legal rules that guarantee the safe conditions of each food product for consumption by consumers and are equipped with correct, honest and responsible information because in general consumers do not know how the process of making each food product is. circulating in the midst of their lives One of these requirements is food labeling.

However, sometimes food products that are widely circulated in the community do not include complete food labels in accordance with applicable regulations. There are also many food business actors who ignore the conditions for the circulation of a food product that causes harm to the community, especially consumers who consume the food product. The government itself has issued various regulations regarding food. However, this is still not enough to monitor every fraud committed by food business actors. Therefore, the government must also supervise the violations committed by business actors or food producers. The existence of BPOM shows that the state has the authority to regulate and intervene in overcoming possible violations that occur by providing a series of regulations that regulate and provide threats, namely sanctions if there is a violation of food product labeling committed by any business actor.

\section{Method}

The type of research used in answering the problem of the discussion of this thesis is normative juridical research, which refers to legal norms contained in laws and regulations and court decisions as well as legal norms that exist in society. This method is also used in order to be able to conduct searches on legal norms contained in the applicable consumer protection laws and regulations, as well as obtain data and information contained in various literatures in libraries, research journals, newspapers, magazines, internet sites and etc.

Normative legal research is a law that is conceptualized as what is written in statutory regulations or the law is conceptualized as a rule based on human behavior that is considered appropriate. The research approach used is descriptive analytical approach, namely research based on one or two interrelated variables based on general theories or concepts that are applied to explain a data set, or show a comparison or relationship between a data set and another data set. And this study also describes or describes the data obtained normatively and then described to conduct a systematic study of the data.

Data analysis in this paper used qualitative data, this qualitative method was used so that the author could understand and understand the symptoms he studied. So this thesis uses a qualitative analysis method to focus more on legal analysis and examines legal materials both from laws and regulations, books, materials from the internet, dictionaries and others related to the title of the thesis that can be used to answer the questions at hand.

\section{Analysis And Results}

\subsection{Consumer Protection In Violations Of Food Product Labeling Based On Law No. 8 Year 1999}

\section{a. Consumer Protection in Violation of Food Product Labels}

It must be realized that business competition is actually needed in a good economic structure. Due to the existence of competition between business actors, consumers have broad freedom and alternatives to obtain consumer goods. The benefits of this can be seen in competitive efforts between business actors in creating quality products, of good standards and satisfying consumers as well as reducing the price of these goods. Globalization and free trade, which are supported by the rapid advancement of telecommunications and information technology (telematics) are increasingly creating a rapid and wide range of movement for the flow of transactions of goods and/or services offered to the market. The goods and/or services offered 
are not only at the level of domestic products but even more rapidly from abroad. The impact on consumers from this condition is that the goods and/or services needed can be fulfilled and they are free to make choices about various types and quality of goods and/or services in accordance with the tastes and abilities of consumers.

On the other hand, such phenomena and conditions can make the consumer's position weak and unbalanced. Even consumers become objects of activity by business actors who exploit them in order to achieve the maximum profit through promotions, sales methods, misleading information about goods, the application of adverse standard promises, empty promises and so on. Marshal B Clinard and Peter C Yeager in their book Corporate Crime in this connection describe that there are so many different intensities of fraudulent and illegal acts that have bad consequences because companies are intentionally committed to consumers, workers and rivals, not caring about foreign trade partners who involving thousands or billions of dollars per year.

More broadly, Kuntjoro Jakti said that there is a wrong interpretation of freedom and unrestricted business practices that whoever is unable to play in the business arena, let him die or resign from his business. This kind of misinterpretation creates a bad image of the community towards business actors who justify the use of all means in obtaining the maximum economic benefit. The fact shows, a variety of important factors as the cause of the weakness of consumers. According to the research results of the National Legal Development Agency $(\mathrm{BPHN})$, the factors that weaken consumers are:

1) The level of consumer awareness of their rights is still low.

2) The consumer community is not yet conditioned because as a society they do not know about their rights and where their rights are distributed if they encounter difficulties or lack of a reasonable standard of goods and/or services.

3) The consumer society has not yet become a society that has the will to demand their rights.

4) The judicial process is complicated and time-consuming.

5) Weak consumer position.

If observed in the social pattern that occurs, the factors mentioned above can be added in the following forms:

1) The politics of development in Indonesia is more flexible for business actors, in the form of loosening legal norms in the application and compliance of consumer law.

2) Inconsistency of the judiciary in its decisions, where there are often differences in court decisions in similar cases.

3) The Indonesian legal system has not yet fully explored and formulated policies to protect consumers.

4) The attraction of various interests among economic actors who are not consumers, which parties have strong access in various lines, including decision makers. This figure is sociologically beyond the reach of the law.

In line with these factors, the results of research by the Indonesian Consumers Foundation (YLKI) and the United Nations, including The International Organization of Consumer's Union (IOCU) concluded that consumers are somewhat reluctant to use law enforcement and judicial institutions to defend their interests because it is not easy to use them. legal means and the high cost of litigation in court.

From these results, it can be concluded that consumers generally do not understand what their rights are and how their rights are guaranteed in the legislation. Likewise, business actors do not understand that there is a prohibition on the actions and habits of business actors, especially regarding the inclusion of labels in the food products they produce. 
Talking about rights, consumers generally doubt how to get effective rights, because it is too inconvenient to just demand but not respond well. Regarding the losses arising from misleading information in food product labels, consumers said they would sue as well. However, where to complain, all do not know except only to the police. Socialization of important provisions in Law no. 8 of 1999 concerning Consumer Protection must be effective and effective. The sanctions that have been regulated in such a way in Article 62 Chapter XIII of Law no. 8 of 1999 concerning Consumer Protection, both civil sanctions, criminal sanctions, and administrative sanctions must be applied in accordance with the sanctions imposed by the Panel of Judges in Court. Therefore, consumer protection against violations of business actors in the inclusion of labels whose information misleads consumers can be realized in accordance with applicable regulations. So that there is no gap between business actors and consumers.

\section{b. Civil, Criminal and Administrative Aspects in Consumer Protection}

Positive law (ius constitutum) is a legal substance that applies at a certain time and place. The specified time is when a legal event occurs. Positive law in other words, the law that is currently in force, not the law in the past or the law that was aspired to (ius constituendum). Positive law is the substance of a legal system. According to Lawrence M. Friedman, the legal system has 3 (three) elements, namely:

1) Structure,

2) substance, and

3) Legal culture.

The legal structure refers to the form and position of legal institutions contained in the legal system. The relationship between high state institutions which is a description of the legal structure. The legal substance is a collection of existing legal values, principles and norms. This is what is commonly known as law in the books in a legal system. Of course, not all legal regulations go according to expectations in the field. There are rules that are obeyed and there are those that are violated. An important element in influencing the pattern of living law is the legal culture of the community that is the subject of the law.

The law of life, grows and develops in society as a means of creating peace and order for peace in the lives of fellow citizens. The growth and development of law occurs when people realize the meaning of legal life in their lives, while the purpose of the law is to achieve peace and order in society. The law is also required to fulfill the basic legal values which include justice, expediency and legal certainty. Positive law which contains various provisions of consumer protection law is also required to fulfill the values of justice, usefulness and legal certainty, despite the fact that one of the basic values of the law can be achieved.

In order for the law to function as a means of social engineering for the consumer community and business actors, an approach by taking Robert Seidman's theory can also be used, namely that the operation of law in society involves three basic components, namely lawmakers/laws, implementing bureaucrats and role holders. The law works well and effectively when it involves 3 (three) basic components, namely law makers, implementing bureaucrats and role holders. Every member of society (consumers and business actors) as role holders, their behavior is determined by the pattern of expected roles, but the operation of those expectations is determined by other factors. These factors are:

1) Sanctions contained in the regulations;

2) Activities of law-implementing institutions or bodies;

3) All social, political and other forces that work on the role holder.

The behavior of consumers and business actors, of course, cannot be separated from the level of knowledge, attitudes towards Law no. 8 of 1999, resulting in an intention to behave. According to Hobbs and Freud, basically individual human behavior is egoistic and therefore tends to 
satisfy its own interests. As a result of human nature which tends to want to satisfy its own interests, it often causes conflicts with other parties which if this is allowed to continue will create social deviations (social deviation). In this case the role of law as an effort to form social behavior in a person to be able to share interests with others is needed.

\author{
c. Responsibility of Business Actors Against Food Product Labeling Violations \\ 1) Civil Liability
}

Providers of goods and/or service providers as business actors have the duty and obligation to participate in creating and maintaining healthy business competition that supports the development of the national economy as a whole. Business actors are charged with the responsibility for the implementation of these duties and obligations, namely through the application of legal norms, propriety, and upholding the prevailing customs in the business world. The principle of business is business, cannot be applied, but is understood with business principles for development. So, it is appropriate that business actors must work hard to make their business contribute to the improvement of overall national development.

The obligation of business actors to have good intentions in carrying out their business activities is a public responsibility carried out by business actors. All provisions in Law no. 8 of 1999 concerning Consumer Protection aims to direct every business actor to behave in accordance with the provisions of the law to succeed in the national economic development in Indonesia, especially in the trade business sector. Every violation committed by a business actor will be subject to sanctions as a legal consequence of the violation. The imposition of sanctions as a result of legal violations is very important, because the world of fair business competition requires seriousness and firmness. The provision of sanctions is one of the tools to restore the situation when there has been a violation (rehabilitation) as well as a preventive tool for entrepreneurs so that the same actions do not happen again.

\title{
2) Criminal Liability
}

In addition to civil responsibilities, consumer protection law also has criminal responsibilities. Positive legal arrangements in the field of criminal law are generally contained in the Criminal Code. In Indonesia, the application of the above book has been unified since 1918, since Wetboek van Strafrecht voor Nederlandsch-Indie was first implemented. In contrast to the Civil Code (KUHPerdata), which is still pluralistic, the codification of criminal law is far from applicable to all population groups. Consumer protection law is also part of criminal law. Consumer rights as regulated in Law no. 8 of 1999 concerning Consumer Protection has a public nuance so that it can be defended through criminal law. The actions of business actors that cause harm to consumers at a certain level of complexity have a criminal dimension. This means that the actions of business actors that violate/harm the rights of consumers that are contrary to the norms of criminal law can be categorized as criminal acts. Therefore, the case must be resolved by criminal law and using a criminal instrument (KUHAP).

Criminal sanctions in the form of fines as stated above, in the Criminal Code (KUHP) are included in the main types of punishment, as can be seen in Article 10 which stipulates that:

The penalties are:
a) Death penalty,
b) prison sentence,
c) confinement penalty,
d) Fines.

Additional penalties are:
a) Revocation of certain rights,
b) confiscation of certain goods, 
c) Announcement of the judge's decision.

The problem is if criminal sanctions in the form of fines imposed for criminal acts committed by business actors with legal entities are only seen as "costs" as well as costs that must be incurred in the context of a company's production operations. Susanto also explained that looking at the practice of law enforcement against violations committed by corporations, it is seen as just a cost, namely a cost or reduction of profits through fines "which are calculated and calculated beforehand in the same way as with any costs that must be incurred to produce profits. and market the products of the corporation concerned.

\section{d. Consumer Dispute Resolution in Food Product Labeling Violations}

Today, public complaints are often found through the column of letters from readers and electronic media. Various kinds of complaints from people's dissatisfaction with certain products to certain services that are inadequate or disappointing. This feeling of dissatisfaction can develop into conflicts experienced by the community. In this case, it is the people who become consumers.

The origin of the dispute begins in a situation where the party who feels aggrieved by the other party. Usually started by feelings of dissatisfaction, subjective and closed experienced by individuals and groups. If feelings of disappointment or dissatisfaction are conveyed to the second party and the second party responds and can satisfy the first party, the conflict is over. On the other hand, if the difference of opinion continues, what is called a dispute will occur. Dispute in the everyday sense is intended as a situation where parties undertaking commercial efforts have a problem, namely wanting the other party to do or not do something but the other party refuses or does not do so.

Until now, civil procedural law does not indicate that representation by legal scholars (verplichte procereurstelling) has certain qualifications to handle disputes/cases in court. This means that consumers can handle their own disputes in court without the help of legal counsel. Subeki believes that without legal assistance from legal counsel, lawsuits are often declared inadmissible due to formatting errors. Lawyers who work in consumer organizations who act as attorneys for consumers, should have met the qualifications required by applicable laws and regulations, either as advocates or lawyers.

Prior to the preparation of the lawsuit, the attorney first receives the power of attorney from the consumer to provide legal assistance to represent the interests of the consumer in court. The form is in the form of a power of attorney that clearly and in detail states what the power is given for (special power of attorney). The existence of errors or defects in the granting of power of attorney can result in the claim being declared inadmissible.

Before composing letter lawsuit should considered several things, namely:

1) First, dig up facts from consumers including anyone from the producers involved in the dispute. So, the attorney is expected not to add facts that are not actually experienced by consumers.

2) Second, study consumer evidence, including letters and witnesses. The results of research/laboratory tests for certain commodities, such as food/beverages, automotive/vehicles, drinking water (PAM), and electricity (PLN), can actually help uncover/prove the arguments of consumer claims.

3) Third, consumer attorneys should explore as far as possible what things consumers have done, such as writing letters to producers, interviews with mass media/electronics or writing letters to readers in the mass media. This is very important to take into account the possibility of a counterclaim in the form of defamation from the manufacturer.

4) Fourth, concerning competence/authority to adjudicate in absolute terms (attribution of judicial power among general courts, religious courts, military courts, or state 
administrative courts) as well as relative judicial authority (among similar courts, which one has the most authority to adjudicate). This relative competence concerns the authority of a similar court to try the Defendant in accordance with the provisions of Article 118 of the HIR. The principle that applies is that the lawsuit is filed in a district court where the Defendant resides (domiciled or if the domicile is unknown, it is filed at the Defendant's actual place of residence (actor sequitur forum rei). The place of residence of a person can be seen from his Identity Card (KTP).

By comparing the weight of the duties and powers that are so broad, as well as the requirements to become a member of BPSK, it is questionable whether there are competent people for this in each region of the Level II Region. Moreover, for members who come from the consumer element, a really mature selection must be made. If the Government is given full authority to appoint and dismiss consumer representatives in BPSK membership, it is feared that there will be a tendency to no longer trust their objectivity in fighting for the interests of consumers when disputing at BPSK.

BPSK's own authority is very limited. The scope of disputes that he has the right to handle only includes violations of Article 19 paragraph (2), Article 20, Article 25, and Article 26. The sanctions imposed are only in the form of administrative sanctions. The definition of administrative sanctions has been influenced by the Common Law system, so that it can be in the form of determining compensation in the provisions of Article 60 of the UUPK. Violations of other articles with criminal nuances are fully the authority of the court. Included in this category are violations of food product labeling, namely Article 8 and Article 10 of Law no. 8 of 1999, even though supervision of the inclusion of food labels according to standards is part of the task of BPSK (provided in Article 52 of Law No. 8 of 1999).

\section{Conclusion}

Food products marketed by business actors, both producers, distributors, and retailers are consumed by consumers, from toddlers to children to adults. Business actors are required to provide correct information and not mislead consumers in the use/use of the food products produced. However, consumers still do not understand what their rights are and how to guarantee their rights. Therefore, Law no. 8 of 1999 concerning Consumer Protection is properly and effectively disseminated to protect any fraud committed by business actors in the labeling of their food products.

In consumer protection regulated in Law no. 8 of 1999 has the substance of civil, criminal and administrative aspects. Starting from the implication of duties and authorities in accordance with the duties of legal officers to provide legal protection to consumers in dispute to the actions of business actors regulated in civil and criminal law.

The dimension of legal protection for consumers in violation of labeling of food products also includes the responsibility of business actors. Violations committed by business actors against food label provisions may be subject to civil, criminal and administrative liability or sanctions. Civil and criminal sanctions are often less effective if they are not accompanied by administrative sanctions. The administrative sanctions given are more effective than civil or criminal sanctions. This is because administrative sanctions can be applied directly and unilaterally, without waiting for a judicial process, civil and/or criminal sanctions often do not bring a "deterrent" effect to the perpetrators. the value of the compensation and the punishment imposed may be insignificant compared to the profits obtained from the violation committed by the business actor. Likewise, the decision-making mechanism is convoluted and requires a long process, so that consumers often become impatient. Settlement of consumer disputes in food product labeling violations is also faced with 2 (two) difficult choices between going 
through court and out of court. Settlement of consumer disputes through the courts often creates a prolonged polemic. Consumers feel that if the problem of losses they experience due to errors in instructions/labeling of food products is sued through the courts, the examination process will take a long time. Also to the decision in court which is very disappointing for consumers because the judge's decision will relieve business actors. Settlement of consumer disputes through out of court is an alternative that is often used by consumers. Settlement is selected through the BPSK route. The lawsuit procedure through BPSK is carried out voluntarily from both parties to the dispute. The membership requirements, duties and authorities of BPSK also make consumers a party that is not weak. BPSK in carrying out its duties does not adhere to a subjectivity view but has an objective view in solving the problem of food product labeling violations in Indonesia. Settlement through BPSK provides an advantage where consumer dispute resolution is carried out simply, quickly, and at low cost. Decisions that have been reached/decided by BPSK to business actors must accept the BPSK decision. Business actors are required to implement the decision no later than 7 (seven) working days from the time they declare their acceptance of the BPSK decision. If the business actor rejects the BPSK decision, but does not file an objection to the District Court after the stipulated period,

\section{References}

Ali, Zainudin, 2009, Legal Research Methods, Sinar Graphic, Jakarta. Arifin, Syamsul, 1992, Philosophy of Law, UNIBA PRESS, Medan.

Asikin, Zainal and Amiruddin, 2003, Introduction to Legal Research Methods, PT. Raja Grafindo Persada, Jakarta.

Barkatullah, Abdul Halim, 2008, Consumer Protection Law Theoretical Studies and Development of Thought, Nusa Media, Bandung.

---------, 2010, Consumer Rights, Nusa Media, Bandung.

Darmodiharjo, Darji \& Sidharta, 1996, Elaboration of Pancasila Values in the Indonesian Legal System, Raja Grafindo Persada, Jakarta.

Djamali, Abdoel, 2006, Introduction to Indonesian Law, PT. Raja Grafindo Perkasa, Jakarta.

Kamello, Tan and Syarifah Lisa, 2010, Civil Law: Person \& Family Law, USU Press, Medan.

Kristiyanti, Celina Tri Siwi, 2009, Consumer Protection Law, Sinar Graphic, Jakarta.

Mertokusumo, Sudikno, 1996, Legal Inventions: An Introduction, Liberty, Jakarta.

Miru, Ahmadi and Sutarman Yodo, 2004, Consumer Protection Law,

PT. Raja Grafindo Perkasa, Jakarta.

Muhammad, Abdulkadir, 2001, Economic Law Study on Intellectual Property Rights, PT. Citra Aditya Bakti, Bandung.

Nasution, Az, 2002, Consumer Protection Law An Introduction, Diadit Media, Jakarta. 2004, Consumer Protection Law An Introduction, CV. Triarga Utama, Jakarta.

Rahardjo, Satjipto, 1991, Legal Studies, PT. Citra Aditya Bakti, Bandung.

1977, Utilization of Social Sciences for the Development of Legal Studies, Alumni, Bandung. 
Samsul, Inocentius, 2004, Consumer Protection, Possibility of Implementing Absolute Responsibility, FH UI Press, Jakarta.

Siahaan, NHT, 2005, Consumer Law, Consumer Protection and Product Responsibility, Panta Rei, Jakarta.

Sidabalok, Janus, 2010, Consumer Protection Law in Indonesia, PT. Citra Aditya Bakti, Bandung.

Sidharta, 2004, Indonesian Consumer Protection Law, PT. Grasindo, Jakarta. -, 2006, Indonesian Consumer Protection Law, PT. Grasindo, Jakarta.

Soekanto, Soerjono, 2007, Introduction Study Law, UniversityIndonesia-UI Press, Jakarta.

Soemitro, Ronny Hanitijo, 1983, Legal Research Methods, Ghalia Indonesia, Jakarta.

Soesilo, R, 1993, The Criminal Code and its Complete Commentaries Article by Article, Politeia, Bogor.

Sophie, Jusuf, 2000, Consumer Protection, PT. Citra Aditya Bhakti, Bandung.

Sri Wahyuni, Endang, 2003, Legal Aspects of Certification \& Its Relation to Consumer Protection, PT. Citra Aditya Bakti, Bandung.

Suggono, Bambang, 2010, Legal Research Methods, Rajawali Press, Jakarta.

Usman, Rachmad, 2003, Intellectual Property Rights Law: Protection and Legal Dimensions in Indonesia, PT. Citra Aditya Bakti, Bandung.

Widjaja, Gunawan \& Ahmad Yani, 2003, Law on Consumer Protection, PT. Gramedia Pustaka Utama, Jakarta.

Decree of the Head of the Indonesian Food and Drug Supervisory Agency Number: HK.00/05.1.2569 concerning Criteria and Procedures for Assessment of Food Products.

Regulation of the Minister of Health of the Republic of Indonesia No. 180/Menkes/Per/IV/1985 concerning expired food which has been amended by Decree of the Director General of POM No. 02591/B/SK/VIII/91.

Government Regulation Number 69 of 1999 concerning Food Labels and Advertisements.

Government Regulation Number 28 of 2004 concerning Food Safety, Quality and Nutrition.

Supreme Court Decision dated March 14, 1987 No. 341 PK/Pdt/1986 in the Ratu Ayu Brand Case, between PT. Rama Pharmaceutical Industry (Application for Judicial Review (PK), Respondent for Cassation/Plaintiff) against Mrs. Martha Tilaar and the Government of Indonesia qq Dep. The Justice of the Republic of Indonesia qq the Directorate of Patents and Copyrights (Respondent for Judicial Review, Petitioner, and Co-Respondent for Cassation/Defendant I/II).

Circular Letter of the Supreme Court of the Republic of Indonesia dated September 5, 1963 No.3/1963, regarding: The idea of Burgerlijk Wetboek is not a law.

Law Number 7 of 1996 concerning Food.

Law Number 8 of 1999 concerning Consumer Protection.

Agnes M. Toar, Product Responsibility and the History of Its Development in Several Countries, Papers in Upgrading the Law of Engagement II in Ujungpandang, 17-29 July 1989.

Ahmadi Miru, Principles of Legal Protection for Consumers in Indonesia, Dissertation for Postgraduate Program in Legal Studies, Airlangga University, Surabaya, 2000. 
Anak Agung Ayu Diah Indrawati, Consumer Legal Protection in Food Product Labeling, Thesis for Postgraduate Program in Law, Udayana University, Denpasar, 2011.

National Legal Development Agency (BPHN): Final Report on Consumer Protection Research on Producer Negligence, Ministry of Justice of the Republic of Indonesia, 1992.

Teaching Materials "Indonesian Civil Procedure Law" course Civil Procedure Law by Muhammad Husni, SH., MH, USU's Assistant Dean III FH.

http://www.google.com/SistemPenanandiIndonesia/UniversitasA irlangga.

http://google.com/skripsipelabelanprodukpangan/ujiskripsititien Pujirahayu200 8, accessed on 29 April 2013.

website: http://sofhianidewi.blogspot.com/pelabelanperisaprodukpangan Consumer News No. 01 Th XXVII January 2000. 